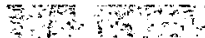

3

This report was prepared as a seientific account of Govenment-sponsored work. Neither the United States, nor the Commission, nor any person acting on behalf of the Commakes ony warraty respect to the represtation, express or implied, with formotion contacuracy, completeness, or usefulness of the information contained in this report, or that the use of ony informoynot infring a fente of or from damages resulting Cx. he of any information, apparatus, me hod, or proceng disclosed in this report.

$-5$

5

is

$+2$

Photostat Charge $\$$ 1f 20 for
Access Permittees

Available from

Technical Information Service

P. O. Box 100́i, Oak Ridge, Tennessee
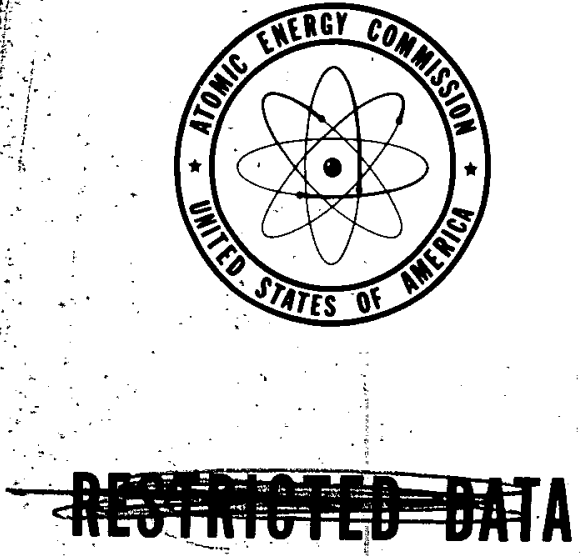

This document contains restricted data as defined in the Atomicstergy Act of 1954. Its tranomitor or the disclosure of its contents in fifinanner to an unauthorized person is prohibited.

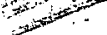

This document contains Confidential Restricted Data relating to civilianapplications of atomicenergy applications

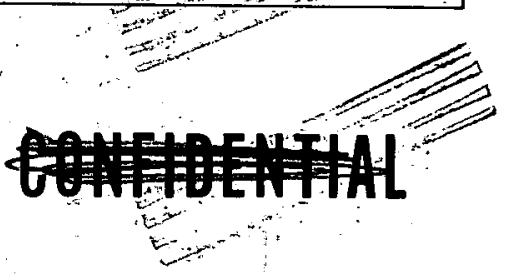

UNITED STATES ATOMIC ENERGY COMMISSION

\section{URANIUM-ALUMINUM DIFFUSION AND ASSOCIATED STUDIES}

By

Samuel Storchheim John Zambrow

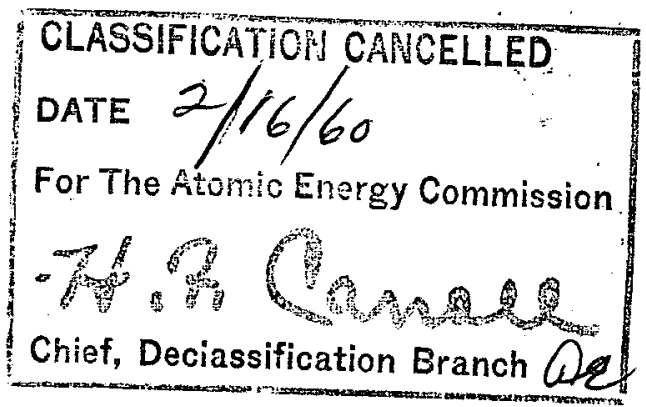

October 30, 1952

Sylvania Electric Products, Inc.

Bayside, New York

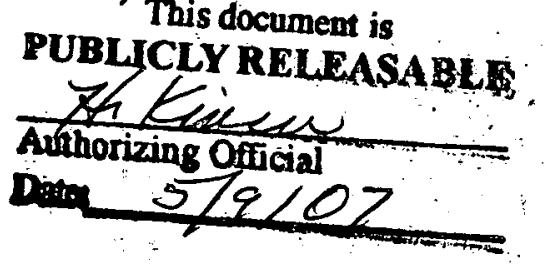

Technical Information Extension, Oak Ridge, Tennessee

\section{AEC RESEARCH AND DEVELOPMENT REPORT}

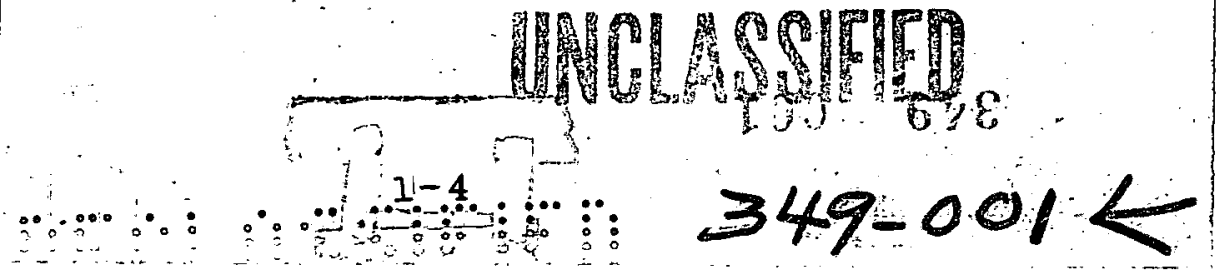




\section{DISCLAIMER}

This report was prepared as an account of work sponsored by an agency of the United States Government. Neither the United States Government nor any agency Thereof, nor any of their employees, makes any warranty, express or implied, or assumes any legal liability or responsibility for the accuracy, completeness, or usefulness of any information, apparatus, product, or process disclosed, or represents that its use would not infringe privately owned rights. Reference herein to any specific commercial product, process, or service by trade name, trademark, manufacturer, or otherwise does not necessarily constitute or imply its endorsement, recommendation, or favoring by the United States Government or any agency thereof. The views and opinions of authors expressed herein do not necessarily state or reflect those of the United States Government or any agency thereof. 


\section{DISCLAIMER}

Portions of this document may be illegible in electronic image products. Images are produced from the best available original document. 


\section{Almages}

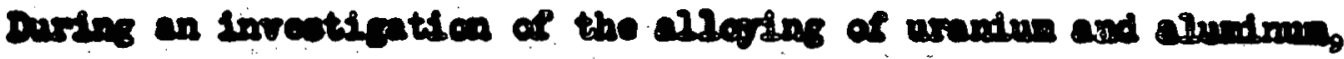

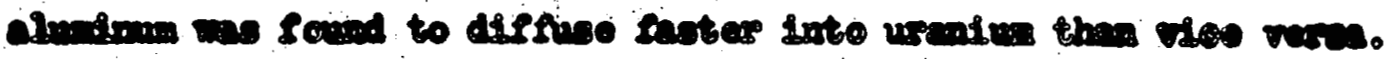

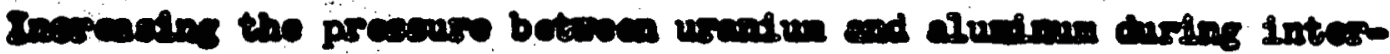

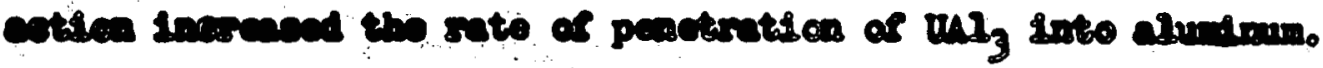

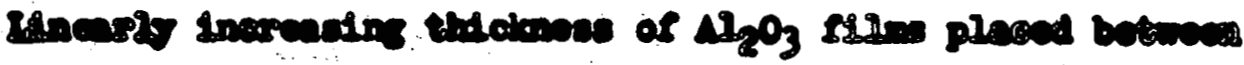

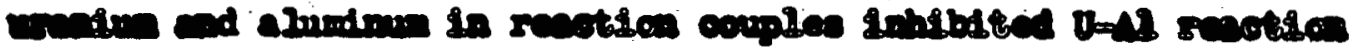

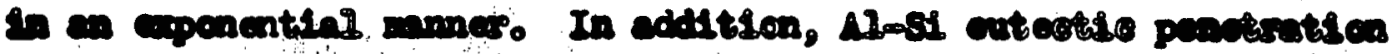

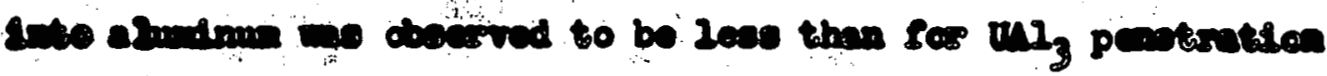
seco alnatimon.

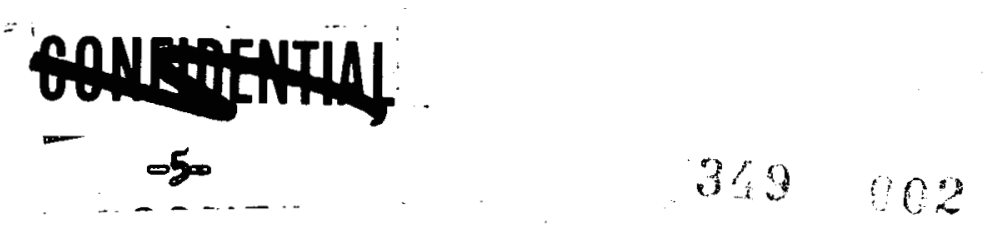

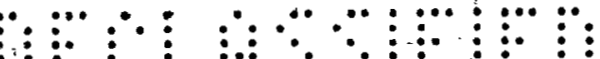




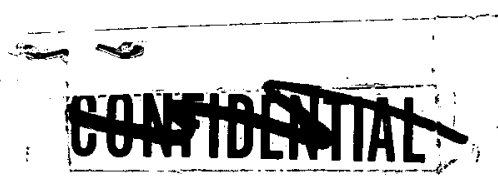

I. INTRODUCTION

A point of importance involving the use of aluminum-jacketed uranium reactor fuel slugs in atomic pile reactors is the diffusion between the uranium and aluminum. It is felt that a better understanding of this phenomenon would be of aid in analyses of slug failures which occur in the piles.

Some quantitative information has been published regarding this uraniumaluminum interaction. One of the important investigations was made by D.W. Bareis(1)*. Among his conclusions were:

a. "The extent of the alloying reaction appeared to increase with increased pressure between the aluminum and urantum surfaces".

b. In the alloying reaction, the aluminum and uranium form $\mathrm{OAl}_{3}$. The uranium diffuses to the aluminum surface through the $\mathrm{UAl}_{3}$ layer.

c. Anodization of the aluminum surface prevents the alloying reaction at $450^{\circ} \mathrm{C}$ and below".

Bareis also determined the temperature effect on the rate of alloy penetration into aluminum. However, he stated that only two direct measurements were used and suggested that many more data were needed to determine the relationship accurately. For comparative purposes, he also gave values for penetration into aluminum as taken from the Oak Ridge report by Williams(2).

The object of this present report is to describe the results of a more detailed study regarding the reaction of aluminum not only with reguline uranium but also with fine-grained uranium as prepared by the hotpressing powder metallurgy technique. Results will also be presented regarding an investigation made concerning the effect that various types and thicknesses of aluminum anodized coatings have upon subsequent uranium-aluminum reaction when placed between them(3). In addition, a study made of the reaction of AI-Si with uranium and Al-Si with aluminum will be discussed. The Al-SI referred to is that presently used in Hanford fuel reactor slugs which acts as: a U-AI diffusion barrier, a $\mathrm{U}-\mathrm{Al}$ bonding material and a corrosion protection agent.

* Numbers in brackets refer to corresponding numbers in the Bibliography at the end of this report.

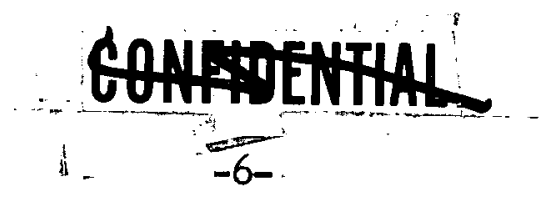

$349 \div 003 \because: \because \because \because \because: \vdots: \because \because: \because$ 
12. PHOCEDURE

A. Types of Materials Used

Reguline, beta-treated uranium was used as a reaction component against $2 s$ aluminum as well as hot-pressed powder metallurey siugs against $2 S$ aluminum. The primary difference between these two uranium materials was that the hot-pressed slugs were very fine grained, 5 to 10 microns in diameter, while the beta-treated slug: *ere about 150 to 200 microns in diameter. The relative purities of the two materials were similar, the hot-pressed material having \$lthely higher contents of nitrogen and iron and a somewhat lower silicon content. In addition, varying thicknesses of differentiy produeed $\mathrm{Al}_{2} \mathrm{O}_{3} \mathrm{fl} 1 \mathrm{~m}$ ware placed between the aluminum and regulthe - hot-pressed urainium metals forming the reaction couples. This was done to determine the effeot the thickness of the $\mathrm{Al}_{2} \mathrm{O}_{3}$ film and upon atimate U-A resetion rates.

So ecplote the experimentel work, ple-abapsd sectloni from the Lewe of a Ianford bonded alug having a 138 S1-41 outootlo alloy wre reacted in a suriace under vacuum.

\section{B Decolption of the Appanstuse and Its operation}

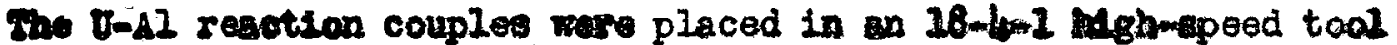
cteel die between two 28-b-l punches. The die hes an 0.0, which

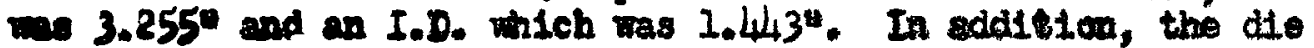

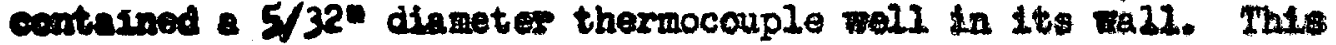
w12 cotended 30 dom frem the top of the die and located $1 / 2$. and from the die I. D. The bottam prom was 1* high, 1.440" in Alemeter and hed $5 / 32$ dianeter thermocouplo well ontraliy 100ated. Fhto mell extended from the botton of the punch to wethis $1 / 8$ of the top of the panch.

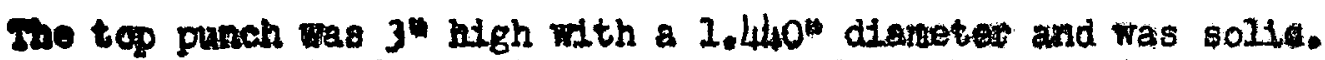
The die assembly fitted into the I.D. of a cylindriagl Hevi-Drty ceramic heating furnace which in turn flttad into rater-0oaled ctalniess steel pot, Af the dis and furnses placed upreght in the pot, the pot was sealed with a watermooled cover.

- For further descriptive Inf armation Fegasding th apparatus us for the diffueican experimente of this report, see reports 180-1129 by H.H. Hasner and N.P. Pinto, Hot-Pressing of Uranium", Sane 16, 2950, and SpP-39 "High Density Urandum by Hot-Vressing" septanber 27, 2950. 
II. PROCEDURE (cont'd)

This cover contained a centrally located Wilson seal with an 18-4-1 punch, one inch in diameter and eight inches long, placed in it. After sealing, the pot was evacuated, the heating coil energized and controlied by means of a variac until both the thermocouples indicated the temperature desired. Once this was accomplished, pressure was applied for a predetermined length of time to the I punch through to the top punch and to the couple. When the time for keeping the couple under pressure elapsed, the pressure was released, the energizing coil current turned off and the assembly allowed to cool. After cooling, the die was removed from the pot and the reaction couple was ejected.

C. Reaction Couple Preparation

After preliminary investigations regarding reaction couple preparation, the following standard conditioning techniques were adopted:

1. Uranium Preparation

The uranium slugs used were first machined to $1.369^{\prime \prime}$ in diameter and $1 / 4^{\prime \prime}$ thick. Immediately prior to couple assembly, the slugs were abraded with 320 silicon carbide paper, producing clean, smooth surfaces on the slugs.

2. Bare Aluminum Preparation

Discs of 25 rolled aluminum rod were used which were machined to $3 / 16^{\prime \prime}$ thick and $1.369^{\prime \prime}$ in diameter. In addition, sleeves of impact extruded 25 aluminum were used to contein and line up the subsequent U-AI disc couples. These sleeves were 1.370 on their I.D., 1.438 on their O.D. and received the same treatment as the aluminum discs. This treatment involved:

a. Degrease in acetoise

b. Immersion in $5 \% \mathrm{NaOH}$ at $80^{\circ} \mathrm{C}$ for five minutes

c. Immersion in $50 \% \mathrm{HNO}_{3}$ at room temperature for three minutes.

d. Water rinse

e. Dry in olast of gas.

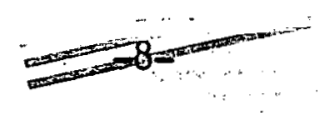


II. PROCEDURE (cont'd)

3. Anodized Aluminum Preparation

$\mathrm{Al}_{2} \mathrm{O}_{3}$ coatings were placed on discs and sleeves in the following manner:

a. Made anodic at 6 volts for 10 seconds in Oakite No. 90 solution

b. Rinsed

c. Pickled in an acid bath at $80^{\circ} \mathrm{C}$ for 10 minutes

d. Rinsed

e. Anodized

The actual anodization* was carried out for varying lengths of time in a number of different type electrolytes including chromic acid, sulfuric acid and phosphoric acid. Anodization was also accomplished by means of immersion for different times in hot baths of either an Alrok or an Alumox solution.

The effect of varying the time of anodization in both type baths was to build up heavier $\mathrm{Al}_{2} \mathrm{O}_{3}$ costs on the aluminum. No satisfactory means was found for determining the actual thicknesses of these costs. Because of this, it was decided to use, as a criterion for $\mathrm{Al}_{2} \mathrm{O}_{3} \mathrm{film}$ thickness measurements, the length of stay of the aluminum in its anodizing bath.

D. Reaction Couple Assembly

Couples were assembled in the following manner:

1. An aluminum disc was placed in an aluminum sleeve.

2. A $3 / 8$ square piece of molybdenum strip was placed on the center of the alumimum disc. The strip was $0.003^{\prime \prime}$ thick.

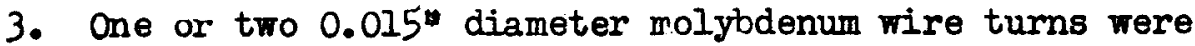
placed flat against the aluminum disc.

* See appendix for detalls of the anodization treatments.

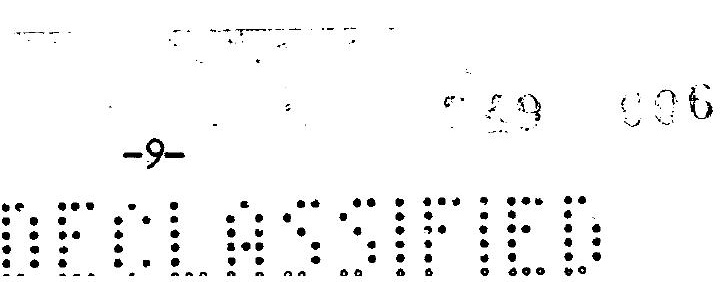




\section{PROCEDURE (cont'd) \\ 4. A uranium slug was placed over the bottom aluminum disc and the molybdenum pieces. \\ 5. Another square molybdenum piece was placed on the uranium plus another turn or two of molybdenum wire. \\ 6. A second aluminum disc was placed on the uranium disc over the molybdenum pieces.}

The molybdenum strips were used as inert markers, since they did not react with either the uranium or the aluminum at the reaction temperatures used. In addition, they prevented U-Al interaction where they came between the uranium and the aluminum and thus acted as reference lines for eventual penetration measurements; $i . \theta .$, the extent of penetration was measured from the U-Al interface, as defined by the mulybdenum strip, up through and to the deepest penetration of the $\mathrm{UAl}_{3}$ intermetallic compound formed. The molybdenum wires were used to determine whether the aluminum diffused faster into the uranium or vice-versa (the Kirkendall effect). This was accomplished by measurement of the distances between the wires after reaction.

B Conditions for Reaction Studies

At first, reaction couples of bare aluminum to bare uranium were made by a hot-pressing technique and were then reacted in vacuo at various tempe ratures for different lengths of time.

The initial hot-pressing of these uranium-aluminum couples was carried out in vacuum at a temperature of $300^{\circ} \mathrm{C}$ under a pressure of 15 tons per square inch for a period of two minutes. This temperature was chosen as no incipient reaction occurred during hot-pressing between beta-treated reguline uranium and aluminum. When using uranium prepared by the hot-pressing technique of powder metallurgy, a slight reaction took place between the uranium and aluminum. The little that did occur was accounted for later in the study.

Since the ultimate penetration data obtained from these studies were so erratic, this method of preparation and reaction of couples was rejected. It was believed the results obtained were of no value because the a luminum expanded in part or in total away from the uranium during the reaction process. The extent of this U-Al parting depended upan the initial hot-pressed mechanical bond between the two. This in turn controlled the ensuing furnace reaction of the couples and in many cases actually prevented reaction.

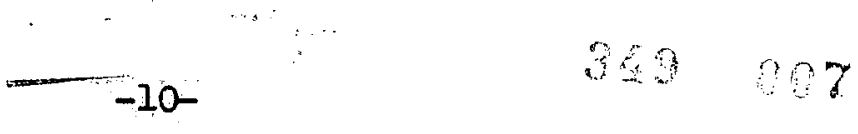

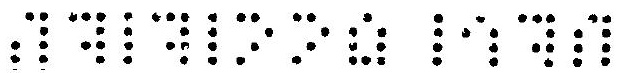




\section{PROCEDURE (cont'd)}

It was, therefore, necessary to use another method for obtaining reliable data regarding the U-Al alloying process. To do this, the same hot-pressing technique was adopted; however, instead of reacting in a furnace at atmospheric pressure, the couples were reacted directly in the hot-pressing apparatus. This method was adopted after initial indications shored it to be satisfactory.

Temperatures used for alloying were $400^{\circ}, 450^{\circ}, 500^{\circ}$ and $550^{\circ} \mathrm{C}$. The reaction couples were pressed at a pressure of 11 tsi, which was maintained for two minutes.

Couples using varying thicknesses of $\mathrm{Al}_{2} \mathrm{O}_{3}$ films between the uranium and the aluminum were hot-pressed at $550^{\circ} \mathrm{C}$ for two minutes at 11 tsi. In addition, 9 tsi was used in another series of experiments.

(Pieces of the Hanford slug were furnace reacted in vacuo at $550^{\circ} \mathrm{C}$ for 20 hours, $500^{\circ} \mathrm{C}$ for 50 hours and at $400^{\circ} \mathrm{C}$ for 168 hours.

F. Penetration Measurements ind Methods of Calculating Penetration Constants:

After a hot-pressed couple was ejected from the die, a quarter-pieshaped section was from it, mounted and the maximum penetration into the aluminum discs was microscopically determined. Once these values were obtained, the penetration constants were calculaṭed from the following formlae:

$$
D=\frac{x^{2}}{t}
$$

$X=$ maximum penetration in $\mathrm{cm}$.

$t$. time at reaction temperature in secionds.

D - pepetration coefficient in cm/sec:

$t^{\prime}=\frac{26.2 \times 10^{-7}}{D}$

$D=D_{0} e^{-\frac{Q}{R^{i T}}}$

$\operatorname{InD}=\ln D_{0}-\frac{Q}{R T}$ $t^{\prime}=$ time in hours to penetrate $.030^{\prime \prime}$ of $25 \mathrm{Al}$

$Q=$ activation energ for penetration in cal/gm-atom

, $R=$ universal gas constant

$T=$ absolute temperature of reaction

$D_{0}=$ intercept on in axis of In $\bar{D}$ vs $\frac{1}{\mathrm{~T}}$ curve 
II. PROCEDURE (cont'd).

A typical view of a quarter section of a couple after mounting may be seen in Fig. 1. Note the fiducial molybdemum wires and the molybdenum strips.

III. RESULTS

In studying the structures formed during U-AI alloying it was observed that typical penetrations were either of the triangular type, Fig. 2, and/or the irregular layer type, Fig. 3. As Bareis noted, there was a black layer between the alumimum and the main reaction product, $\mathrm{JAl}_{3}$. In addition, a greyish appearing constituent was found to exist either between the uranium and $\mathrm{UAl}_{3}$ or else to extend from the uranium into the $\mathrm{UAl}_{3}$ as thinning vein-like growths. The cracks seen in the $\mathrm{UAl}_{3}$ of Fig. 3 Indicate $\cdot$ its brittleness.

A. Reguline Uranium vs. Aluminum

Bare, beta-treated :eguline uranium vs bare $2 \mathrm{~s}$ aluminum was reacted at various tcmperatures for two minutes at 11 tsi. The resultis obtained wexe as follows:

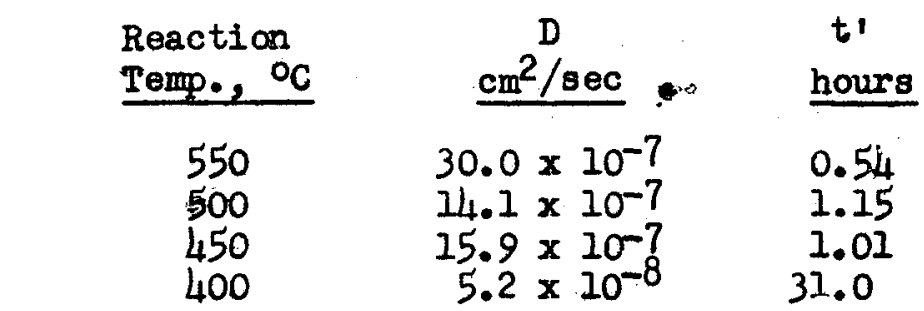

$$
\begin{aligned}
& Q=29,400 \mathrm{cal} / \mathrm{gm}-a t o m \\
& D_{0}=4.1 \times 10^{2} \mathrm{~cm}^{2} / \mathrm{sec}
\end{aligned}
$$

When reacted at $500^{\circ} \mathrm{C}$ for two minutes under a pressure of 9 tsi, the $D=9.8 \times 10^{-7} \mathrm{~cm}^{2} / \mathrm{sec}$ and $t=1.64$ hours.

B. Hot-Pressed Uranium vs. Aluminum

Hot-pressed powder metallurgy uranium slugs were reacted bare against bare $2 \mathrm{~s}$ aluminum at the four different temperatures of above at 11 tsi for two minutes. The data obtained were: 
Top Al Disc

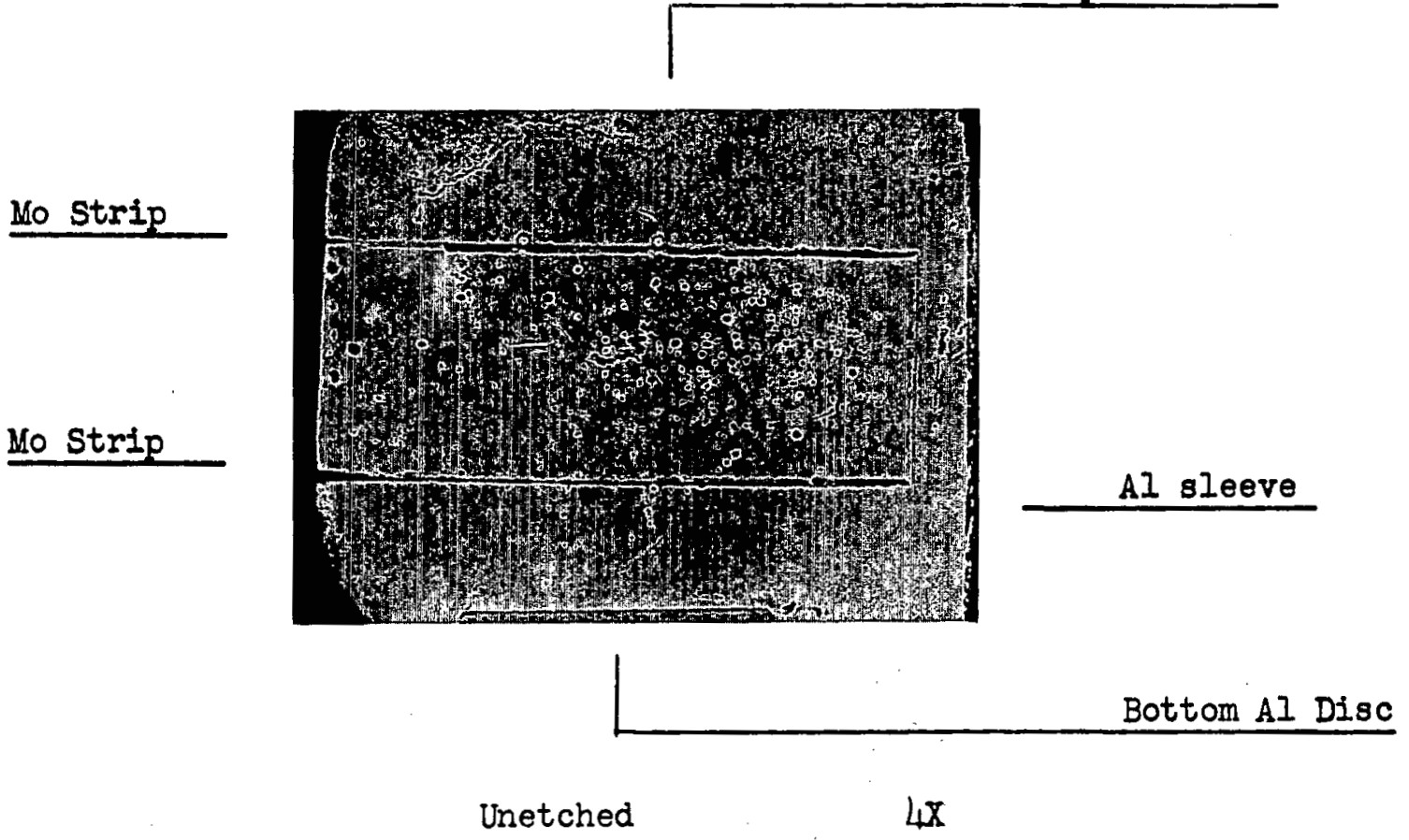

FIg. 1 - View of a quarter section of a reacted U-AI couple showing fiducial Mo wires and Mo strips. Note the reaction product where direct U-AI contact occurred and the lack of interaction where the Mo strips prevented U-Al contáct. Also observe how the Mo wires were pushed up into the $A I$ away from the original U-Al interface as represented by the Mo strip-U interface.

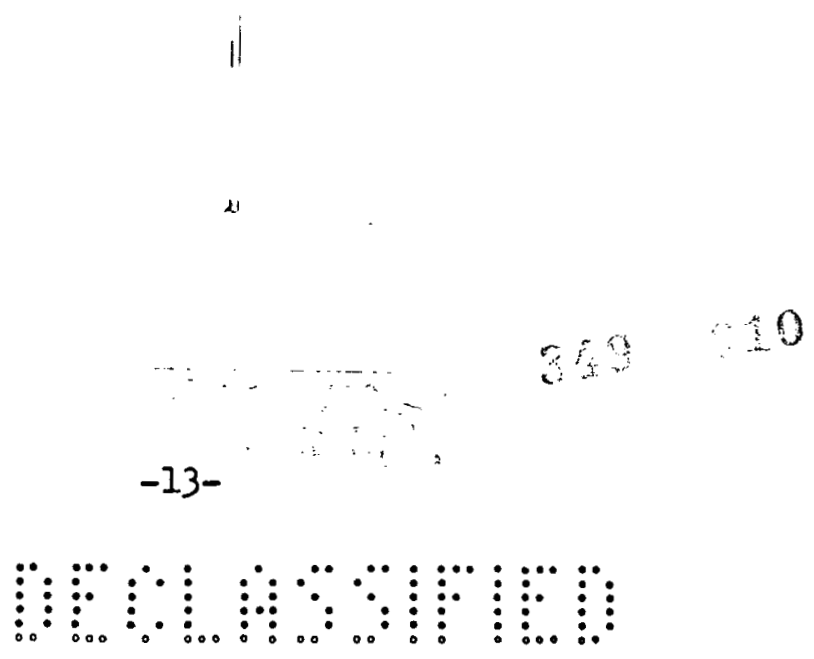




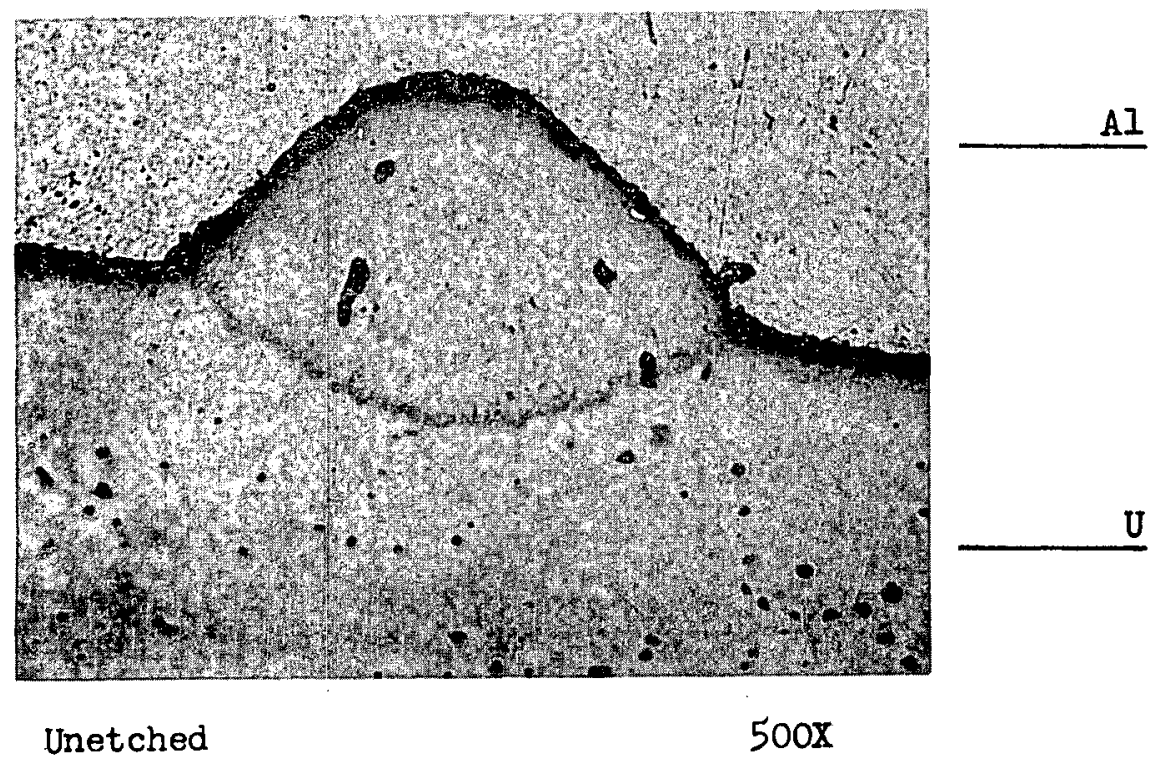

Fig. 2 - Typical triangular U-Al compound formation after reacting bare $U$ against bare $A I$. In this case reaction was carried out at $450^{\circ} \mathrm{C}$ at 11 tsi for 2 minutes in vacuo.

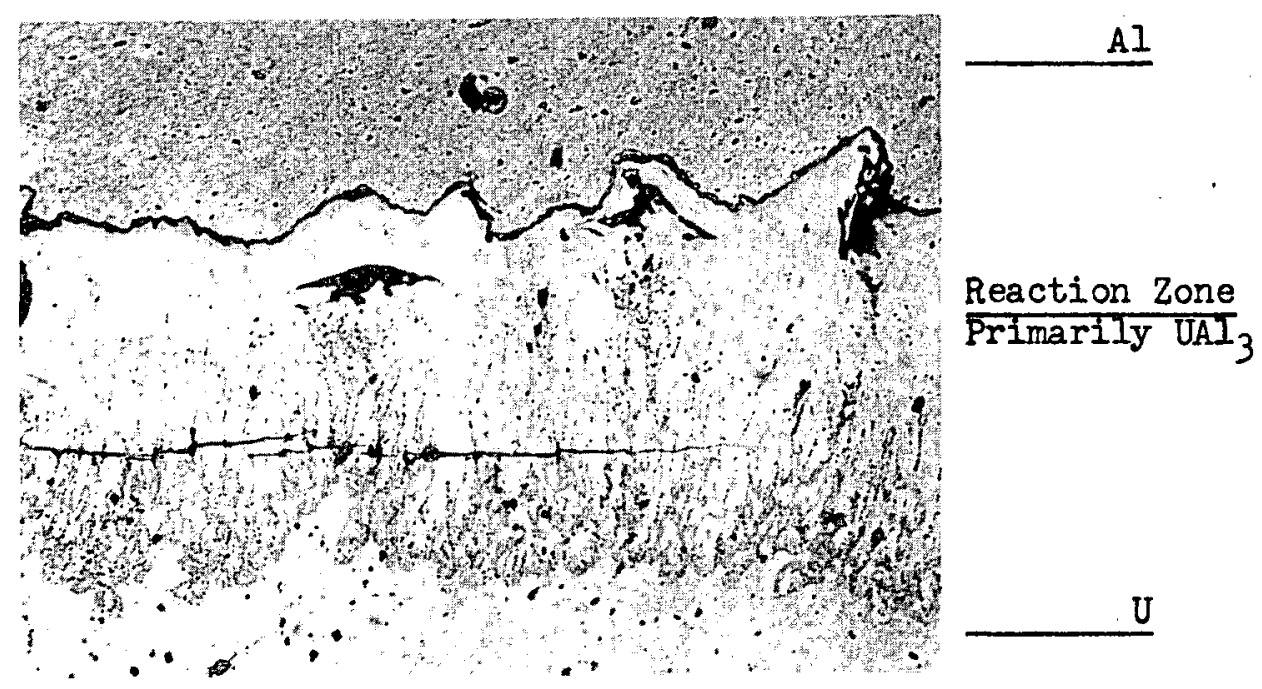

Unetched

$500 x$

Fig. 3 - Typical irregular layer penetration zone obtained between $U$ and $A I$ after reacting in vacuo at $500^{\circ} \mathrm{C}$ under a pressure of 11 tsi held for 2 minutes. Note crack running horizontally through reaction $z$ one and large amount of reaction product fanning out from the $U$ side into the reaction $z$ one. Also note black substance between $\mathrm{AI}$ and $\mathrm{UAl}_{3}$ :-

$$
34901
$$


III. RESULTS (cont'd)

\begin{tabular}{ccc}
$\begin{array}{c}\text { Reaction } \\
\text { Temp. }{ }^{\circ} \mathrm{C}\end{array}$ & $\underline{\mathrm{cm}^{2} / \mathrm{sec}}$ & $\begin{array}{c}\text { t', } \\
\text { hours }\end{array}$ \\
\hline 550 & $20.9 \times 10^{-7}$ & 0.77 \\
500 & $88.4 \times 10^{-8}$ & 1.83 \\
450 & $40.0 \times 10^{-8}$ & 4.04 \\
400 & $14.6 \times 10^{-8}$ & 10.5
\end{tabular}

$$
\begin{aligned}
& Q=19,300 \mathrm{cal} / \mathrm{gm}-\mathrm{atom} \\
& D_{0}=1.6 \times 10^{1} \mathrm{~cm}^{2} / \mathrm{sec} .
\end{aligned}
$$

C. Varying Thicknesses of $\mathrm{Al}_{2} \mathrm{O}_{3}$ Barrier

Films between Uranium and Aluminum

As discussed before, varying thicknesses of differently produced $\mathrm{Al}_{2} \mathrm{O}_{3}$ films were placed between uranium and aluminum in reaction couples. The data regarding these couples including the calculated time to penetrate $.030^{\mathrm{H}}$ of $2 \mathrm{~s}$ aluminum at various temperatures,

\begin{tabular}{|c|c|c|c|c|c|c|}
\hline \multirow[b]{2}{*}{$\begin{array}{l}\text { Anodization } \\
\text { Bath } \\
\end{array}$} & \multirow[b]{2}{*}{$\begin{array}{l}\text { Time in } \\
\text { Bath, min. }\end{array}$} & \multicolumn{3}{|c|}{ Reaction Conditions } & \multirow[b]{2}{*}{$\begin{array}{r}\text { t', } \\
\text { hrs. }\end{array}$} & \multirow[b]{2}{*}{ U Type } \\
\hline & & $\begin{array}{c}\text { Temp. } \\
{ }^{\circ} \mathrm{C} \\
\end{array}$ & $\begin{array}{c}\text { Pressure, } \\
\text { tsi } \\
\end{array}$ & $\begin{array}{l}\text { Time, } \\
\text { min. }\end{array}$ & & \\
\hline $\begin{array}{l}\text { None } \\
\text { None } \\
\text { Chromic acid } \\
\text { Chromic acid } \\
\text { Chromic acid } \\
\text { Chromic acid } \\
\text { Chromic acid }\end{array}$ & $\begin{array}{l}0 \\
0 \\
5 \\
10 \\
15 \\
15 \\
30\end{array}$ & $\begin{array}{l}550 \\
550 \\
550 \\
550 \\
550 \\
550 \\
550\end{array}$ & $\begin{array}{r}9 \\
11 \\
11 \\
11 \\
11 \\
9 \\
11\end{array}$ & $\begin{array}{l}2 \\
2 \\
2 \\
2 \\
2 \\
2 \\
2\end{array}$ & $\begin{array}{l}1.64 \\
0.54 \\
1.95 \\
3.3 \\
5.8 \\
3.5 \\
\infty\end{array}$ & $\begin{array}{l}\text { Reguline } \\
\text { Reguline } \\
\text { Reguline } \\
\text { Reguline } \\
\text { Reguline } \\
\text { Reguline }\end{array}$ \\
\hline $\begin{array}{l}\text { Sulfuric acid } \\
\text { Sulfuric acid } \\
\text { Sulfuric acid }\end{array}$ & $\begin{array}{r}7.5 \\
10 \\
30\end{array}$ & $\begin{array}{l}550 \\
550 \\
550\end{array}$ & $\begin{array}{r}11 \\
11 \\
9\end{array}$ & $\begin{array}{l}2 \\
2 \\
2\end{array}$ & $\begin{array}{c}0.97 \\
8.6 \\
\infty\end{array}$ & $\begin{array}{l}\text { Reguline } \\
\text { Reguline } \\
\text { Reguline }\end{array}$ \\
\hline $\begin{array}{l}\text { Alumox } \\
\text { Alumox } \\
\text { Alumox }\end{array}$ & $\begin{array}{r}1 \\
2.5 \\
15\end{array}$ & $\begin{array}{l}550 \\
550 \\
550\end{array}$ & $\begin{array}{l}9 \\
9 \\
9\end{array}$ & $\begin{array}{l}2 \\
2 \\
2\end{array}$ & $\begin{array}{r}3.4 \\
3.4 \\
55.0\end{array}$ & $\begin{array}{l}\text { Hot Pressed } \\
\text { Hot Pressed } \\
\text { Hot Pressed }\end{array}$ \\
\hline
\end{tabular}
$t$ ', were as follows: 
III. RTSULTS (cont'd)

D. Aluminum-Silicon Eutectic vs. Aluminum

Pieces of an as-received Hanford Al-Si canned slug were furnace reacted and the data obtained for the Al-Si eutectic penetration into the aluminum can were:

\begin{tabular}{|c|c|c|c|}
\hline $\begin{array}{l}\text { Reaction } \\
\text { Temp., }{ }^{\circ} \mathrm{C} \\
\end{array}$ & $\begin{array}{c}\text { Time at } \\
\text { Temperature, } \\
\text { hours } \\
\end{array}$ & $\begin{array}{c}\mathrm{D}, \\
\mathrm{cm}^{2} / \mathrm{sec} \\
\end{array}$ & t \\
\hline $\begin{array}{l}550 \\
450 \\
400\end{array}$ & $\begin{array}{r}5 \\
97 \\
168\end{array}$ & $\begin{array}{l}35.9 \times 10^{-8} \\
22.0 \times 10^{-9} \\
6.48 \times 10^{-10}\end{array}$ & $\begin{array}{l}4.50 \mathrm{hrs} . \\
73.5 \mathrm{hrs} . \\
104 \text { days }\end{array}$ \\
\hline
\end{tabular}

$Q=49,500 \mathrm{cals} / \mathrm{gm}-2$ tom

$D_{0}=6.8 \times 10^{6} \mathrm{~cm}^{2} / \mathrm{sec}$

Fig. 4 represents the as-received condition of the Hanford slug, while Fig. 5 represents an 2s-reacted condition of a piece of the
Hanford slug.

E. Aluminum-Silicon Butectic Intermetallic

Compound vs. Uranium

Only Al-Si eutectic penetration constants into the aluminum were determined. This was caused by the fact that the uranium always fell away from the balance of the reacted piece and accurate penetration measurements wore not feasible.

IV. DISCUSSION

A. Uranium-vs-Aluminum Reaction Couples

1. Effect of Temperature

For ease of comparison, In D vs $\frac{1}{7}$ curves mere plotted in Fig. 6, from the data of the uranium-vs-aluminum experiments. The curves were primarily of the straight-line type indicating that the data conformed to the equation

$$
D=D_{0} e^{-\frac{Q}{R T}}
$$



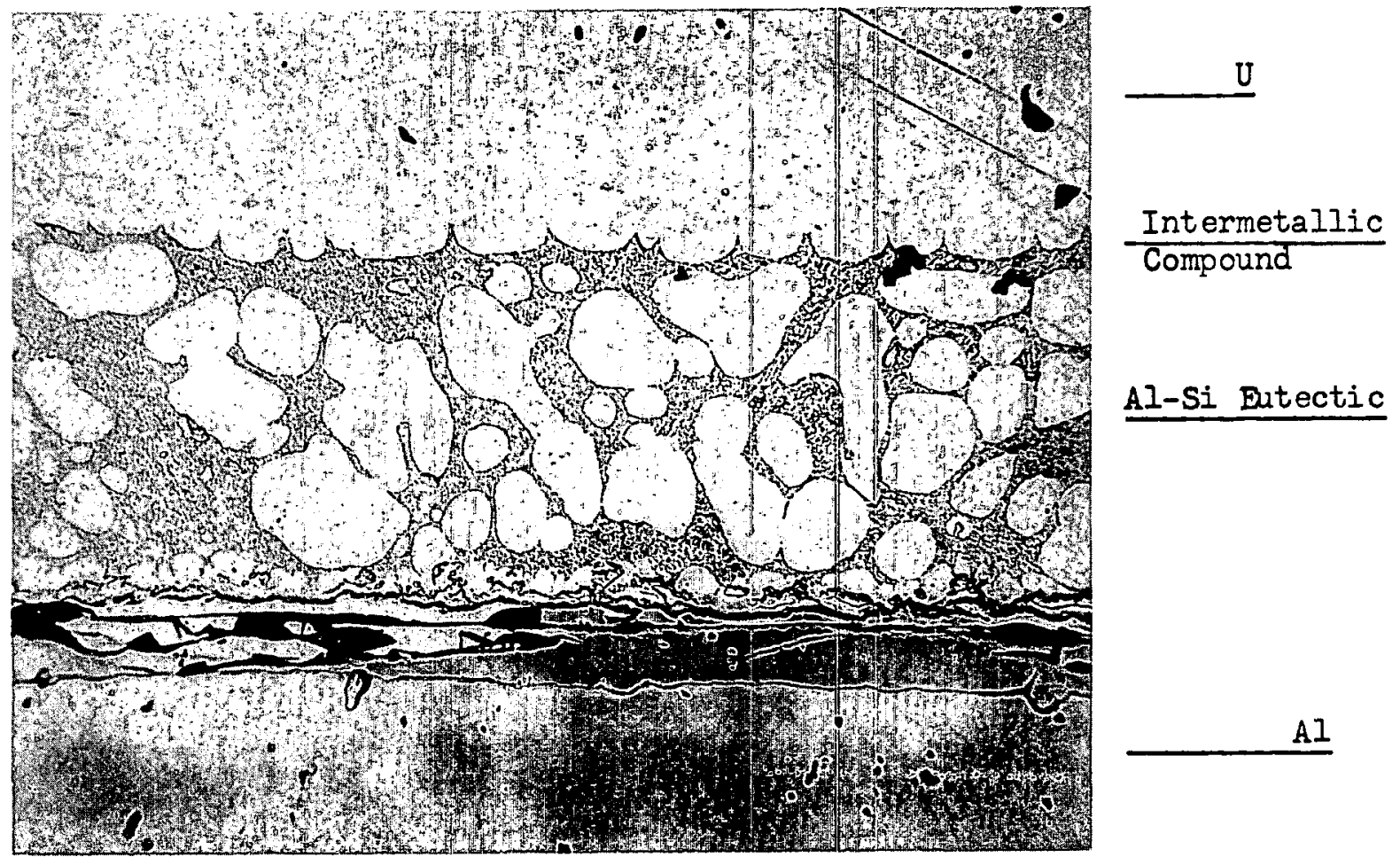

$\mathrm{HCl}$ and Oxalic Acld Etched

$200 x$

Fig. 4 - Hanford slug showing the as-received condition of the U-AI-Si Eutectic-Al interfaces.

Al

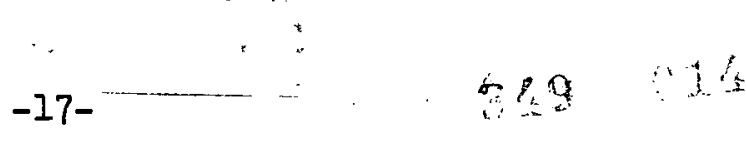



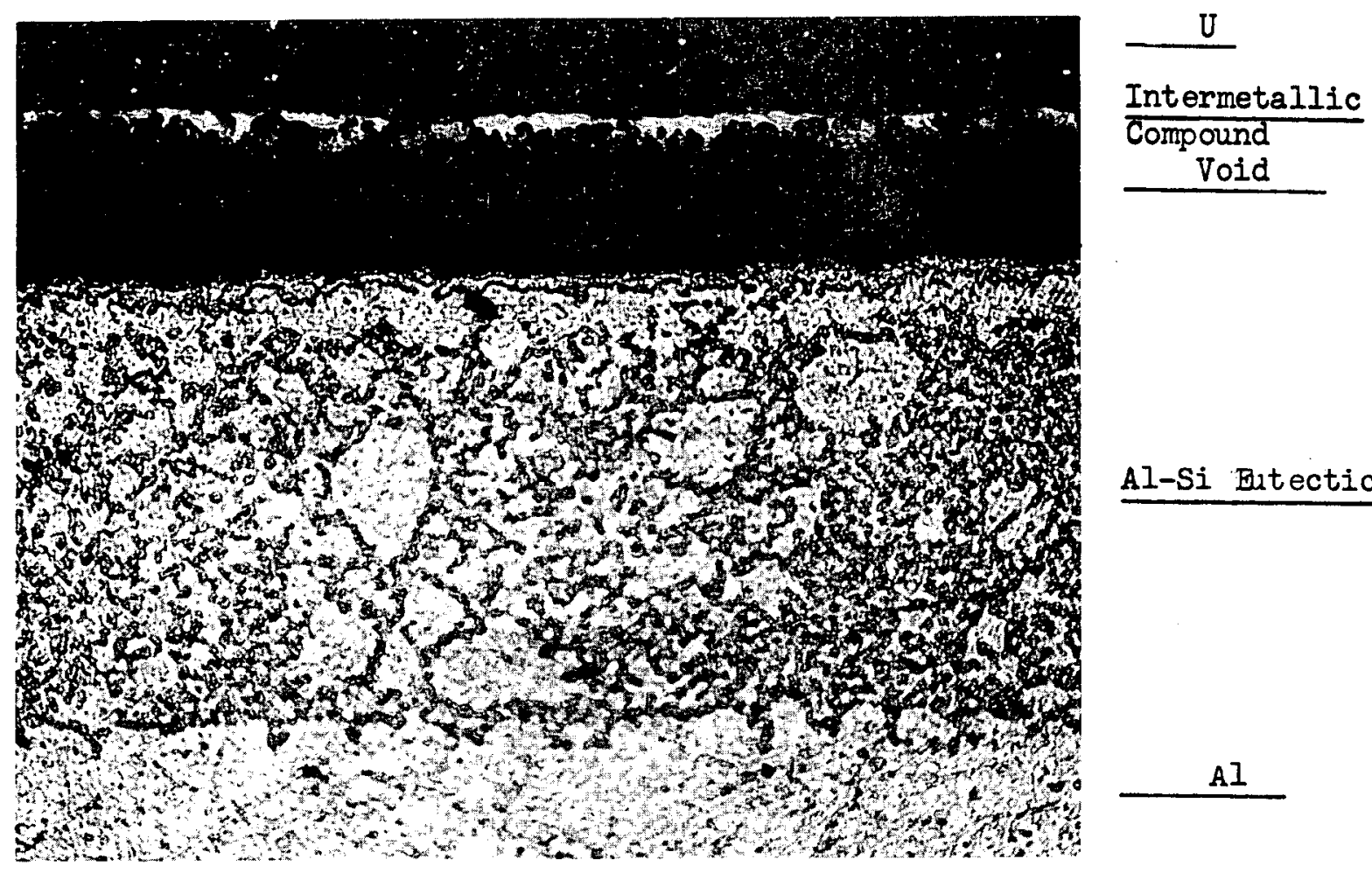

Al-Si Butectic

Oxalic Acid Etched

$200 \mathrm{X}$

Fig. 5 - Hanford slug, U-Al-Si Eutectic-Al interfaces after being reacted at $400^{\circ} \mathrm{C}$ for 168 hours in vacuo. 
ชิ

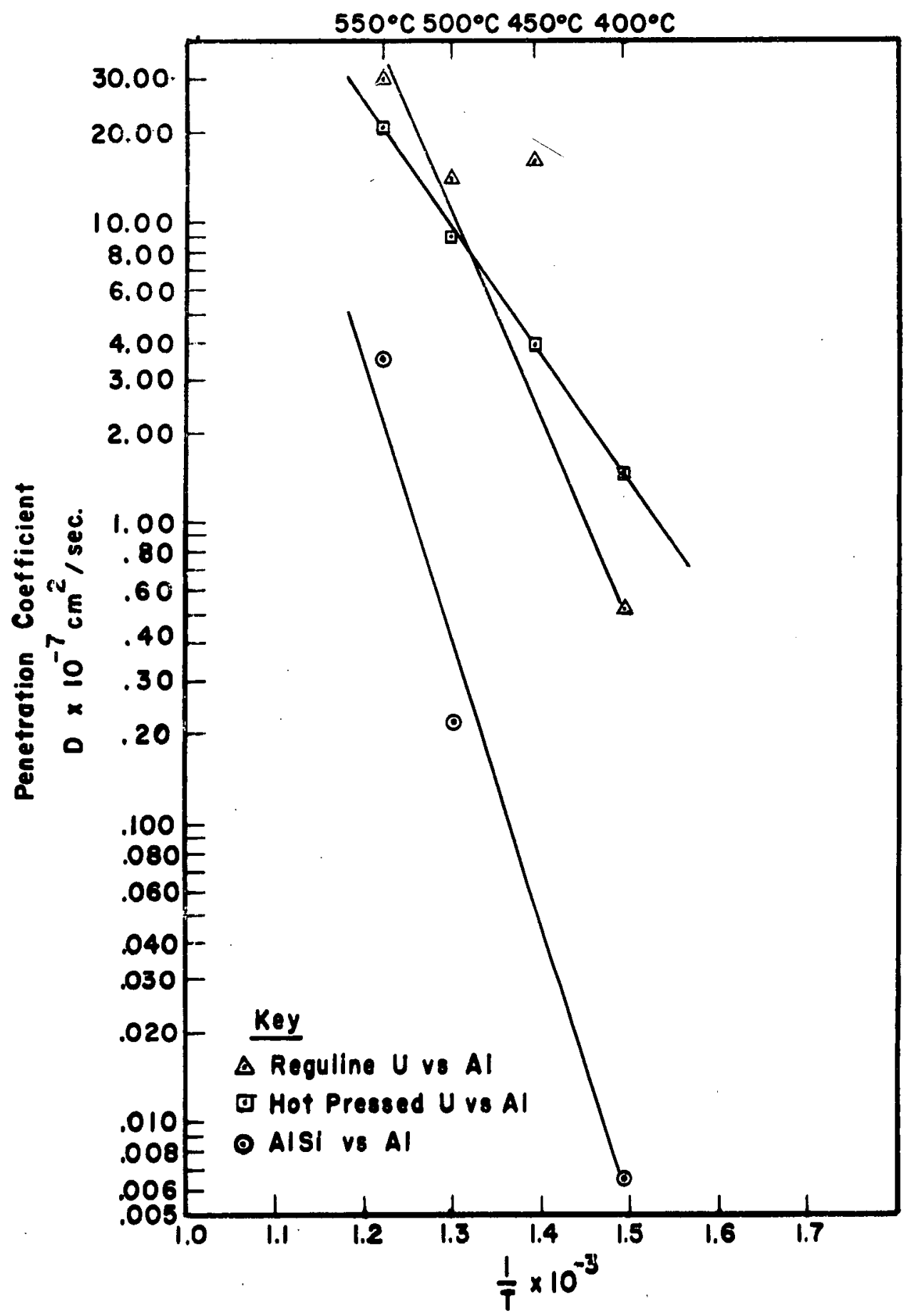

F1g. 6 Ponotration as a function of tomporature for rogulino uranium 1nto aluminum, hotpressed uranium Into aluninum, and AI-S1 outect lo alloy Into aluminus

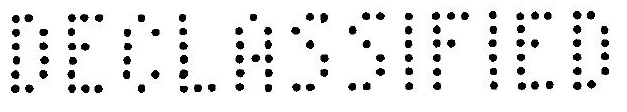




\section{DISCUSSION (cont'd)}

and that the activation energies of reaction calculated could be taken as representative of the penetration process investigated. In addition, it was seen from the straightline curves produced that the process was temperature dependent in the manner that other penetration phenomenon were. Comparison with Bareis' data, see Table I-A, showed that both his activation energies and the values obtained for this report were reasonable and within fairly good agreement, this for bare uranium to bare aluminum reaction. It was noted that the curves for the hot-pressed urantum and reguline uranium were quite similar.

\section{TABLE I}

\section{PENETRATION CONSTANTS OBTAINED WHEN ALLOYING}

A. Bare Uranium to Bare 2S Aluminum

\begin{tabular}{|c|c|c|c|c|}
\hline & BNL* & ORNL* & Hot-Pressed U & Beta-Treated U \\
\hline$D_{0}\left(\mathrm{~cm}^{2} / \mathrm{sec}\right)$ & 1.1 & $1.9 \times 10^{-4}$ & $1.6 \times 10^{1}$ & $4.1 \times 10^{2}$ \\
\hline$Q$ (cal/g-atom) & 24,000 & 15,000 & 19,300 & 29,400 \\
\hline
\end{tabular}

B. Aluminum-Silicon Butectic to 25 Aluminum

$$
\begin{array}{ll}
D_{0}\left(\mathrm{~cm}^{2} / \mathrm{sec}\right. & 6.8 \times 10^{6} \\
Q \quad(\mathrm{cal} / \mathrm{gm} \text {-atom }) & 49,500
\end{array}
$$

* Data as obtained from D.W. Bareis' report(1).

\section{Effect of Pressure}

The effect of change in pressure was specifically noted when two couples using reguline uranium were reacted at $550^{\circ} \mathrm{C}$ for two minutes, one at a pressure of $11 \mathrm{tsi}$, the other at a pressure of 9 tsi. The rate of penetration for the 9 tsi pressed couple was lower than for the couple pressed at the higher pressure. In addition to this, it 


\section{DISCUSSION (cont'd)}

was observed in all the couples reacted under pressure, that penetration was considerably less extensive at the side U-Al interface than at the top or bottom interfaces. Since pressure along the sides of the reaction couple was always lower than that at the top and bottom interfaces, it appeared that Bareis' conclusion of increased pressure increasing the alloying reaction was true.

Bareis' remark that uranium diffused to the aluminum surface through the $\mathrm{UAl}_{3}$ reaction layer would indicate that he was of the ouinion that the uranium diffused faster into aluminum than vice versa. The relative results of the fiducial marker measurements indicated that aluminum actually diffused faster into the uranium than uranium into aluminum. The measurements always showed movement of the markers into the aluminum awy from the uranium. Some actual marker movement values obtained for bare uranium to bare aluminum reaction were:

\begin{tabular}{|c|c|c|c|c|}
\hline \multicolumn{3}{|c|}{ Reaction Conditions } & \multirow{2}{*}{$\begin{array}{l}\text { Movement of } \\
\text { markers away } \\
\text { from each other, } \\
\mathrm{cm}\end{array}$} & \multirow[b]{2}{*}{$\begin{array}{l}\text { Type } \\
\text { Uranium }\end{array}$} \\
\hline $\begin{array}{l}\text { Temp. } \\
{ }^{\circ} \mathrm{C}\end{array}$ & $\begin{array}{c}\text { Pressure, } \\
\text { tsi }\end{array}$ & $\begin{array}{l}\text { Time, } \\
\text { min. }\end{array}$ & & \\
\hline $\begin{array}{l}550 \\
500 \\
550 \\
500 \\
400\end{array}$ & $\begin{array}{l}11 \\
11 \\
11 \\
11 \\
11\end{array}$ & $\begin{array}{l}2 \\
2 \\
2 \\
2 \\
2\end{array}$ & $\begin{array}{l}0.010 \\
0.010 \\
0.015 \\
0.005 \\
0.005\end{array}$ & $\begin{array}{l}\text { Reguline } \\
\text { Reguline } \\
\text { Hot-Press ed } \\
\text { Hot-Pressed } \\
\text { Hot-Pressed }\end{array}$ \\
\hline
\end{tabular}

Possibly, the reason for the marker movement values not falling into a logical plot when graphed as a function of temperature was that the formation of the $\mathrm{UAl}_{3}$ layer was irregular, Fig. 3. This was not only true of the experiments of this report, but also those of Bareis, and can be seen as wel? in Fig. 7 of his report. Thus, the tendency was for the molybdenum wires to move, but not necessarily in a manner which could be coordinated with movement in other diffusion couples. This would aid in explaining the apparent discrepancies in the date, e.g., the same amounts of movements for reguline uranium at temperatures of $550^{\circ} \mathrm{C}$ and $500^{\circ} \mathrm{C}$ and at $500^{\circ} \mathrm{C}$ and $400^{\circ} \mathrm{C}$ for hot-pressed uranium.

-21- 963018


IV. DISCUSSION (cont'd)

B. Varying Thicknesses of $\mathrm{AI}_{2} \mathrm{O}_{3}$

Barrier Films

Parte of the date of Section III-C of this report, i. $\theta$. , Increasing $\mathrm{Al}_{2} \mathrm{O}_{3}$ thicknesses and time for uranium to penetrate through the $\mathrm{Al}_{2} \mathrm{O}_{3}$ film and through $0.030^{\text {w }}$ of 25 aluminum were studied. These indicated that the U-AI interaction was inhibited very markedly with increasing time for the aluminum in the anodizing baths. It appeared that for a 15-minute time of anodization the sulfuric acid type $\mathrm{Al}_{2} \mathrm{O}_{3}$ film was most effective in preventing interaction, the alumax type was next most effective and the chromic acid type was the least effective.

Although the results of the bare uranium and a luminum penetration investigation showed increasing pressure caused increased penetration, the use of $\mathrm{Al}_{2} \mathrm{O}_{3}$ barrier films showed that decreasing the hot-pressing pressure tended to allow a greater amount of U-AI interaction. An explanation for this latter phenomenon would be as follows: The types of anodized films used for this work were known to be porous. Applying compressive forces to them caused them to be crushed and interlocking pore areas to be consolidated. The degree of pore area consolidation would control the resultant U-Al interaction, i.e., the greater the pressure, the greater the pore consolidation and the less the resultant U-AI alloying. In addition, the thicker the film, the less the pore continuity through it and thus the less the interaction for the uranium and aluminum. Should it be made thick enough, penetration through it would cease. This was found to be the case and was a confirmation of Bareis findings that an $\mathrm{Al}_{2} \mathrm{O}_{3}$ film placed between uranium and aluminum prevented their subsequent reaction.

The use of various thicknesses of phosphoric acid and Alrok type $\mathrm{Al}_{2} \mathrm{O}_{3}$ films as diffusion barriers was also attempted. However, generally erratic results were obtained with these films. This indicated that the films were not sufflciently continuous and/nor reproducible in thickness to cause U-Al reaction to be inhibited in a systematic manner. Further work with these anodization treatments was, therefor $\theta$, discontinued.

For a better understanding of the effect $\mathrm{Al}_{2} \mathrm{O}_{3}$ films had upon U-AI interaction, a typical view of partial $\mathrm{Al}_{2} \mathrm{O}_{3}$ film inhibition to hot-pressed uranium ve aluminum interaction is shown in Fig. 7. In this case, the $\mathrm{Al}_{2} \mathrm{O}_{3} \mathrm{film}$ was produced by a 20-minute immersion in an Alrok anodizing bath. Observation should be made of the partial penetrations after reacting at $550^{\circ} \mathrm{C}$ in vacuo at a pressure of 9 tsi

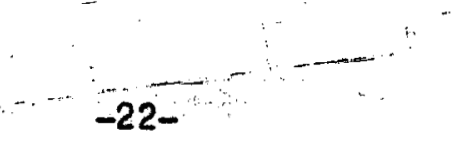

$$
35099
$$




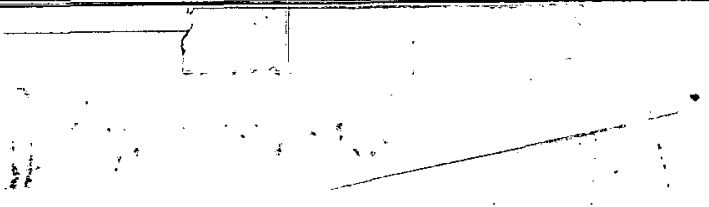

IV. DIscussIon (cont'd)

B. Varying Thicknesses of $\mathrm{A \perp}_{2} \mathrm{O}_{3}$

Barrier Films

Parte of the data of Section III-C of this report, $1 . \theta_{.}$, 1ncreasing $\mathrm{Al}_{2} \mathrm{O}_{3}$ thicknesses and time for uranium to penetrate through the $\mathrm{Al}_{2} \mathrm{O}_{3}$ film and through $0.030^{\text {w }} 2 \mathrm{~s}$ aluminum were studied. These indicated that the $\mathrm{U}-\mathrm{Al}$ interaction was inhibited very markedly with increasing time for the aluminum in the anodizing baths. It appeared that for a 15-minute time of anodization the sulfuric acid type $\mathrm{Al}_{2} \mathrm{O}_{3}$ film was most effective in preventing interaction, the alumox type was next most effective and the chromic acid type was the least effective.

Although the results of the bare uranium and aluminum penetration investigation showed increasing pressure caused increased penetration, the use of $\mathrm{Al}_{2} \mathrm{O}_{3}$ barrier films showed that decreasing the hot-pressing pressure tended to allow a greater amount of U-AI interaction. An explanation for this latter phenomenon would be as follows: The types of anodized films used for this work were know to be porous. Applying compressive forces to them caused them to be crushed ana interlocking pore areas to be consolidated. The degree of pore area consolidation would control the resultant U-Al interaction, i.e., the greater the pressure, the greater the pore consolidation and the less the resultant $U-A I$ alloying. In addition, the thicker the film, the less the pore continuity through it and thus the less the interaction for the uranium and aluminum. Should it be made thick enough, penetration through it would cease. This was found to be the case and was a confirmation of Bareis findings that an $\mathrm{Al}_{2} \mathrm{O}_{3}$ film placed between uranium and alumimum prevented their subsequent reaction.

The use of various thicknesser of phosphoric acid and Alrok typo $\mathrm{Al}_{2} \mathrm{O}_{3}$ films as diffusion barriers was also attempted. However, generally erratic results were obtained with these films. This indicated that the films were not sufficiently continuous and/nor reproducible in thickness to cause U-Al reaction to be inhibited in a systematic manner. Further work with these anodisation treatments was, therefore, discontinued.

For a better understanding of the effect $\mathrm{Al}_{2} \mathrm{O}_{3}$ films had upon U-AI interaction, a typical view of partial $\mathrm{Al}_{2} \mathrm{O}_{3}$ 到lm Inhibition to hot-pressed uranium vs aluminum interaction is show in Fig. 7 . In this case, the $\mathrm{Al}_{2} \mathrm{O}_{3}$ film was produced by a 20-minute immersion in an Alrok anodizing bath. Observation should be made of the partial penetrations after reacting at $550^{\circ} \mathrm{C}$ in vacuo at a pressure of 9 tsi

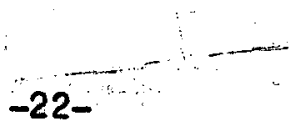




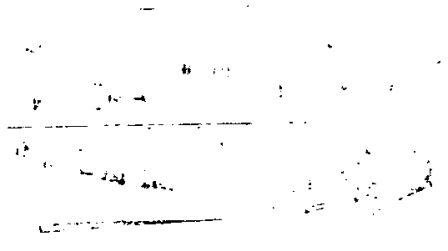

IV. DISCUSSION (cont'd)

held for 2 minutes. In addition, note should be taken of the manner in which the $\mathrm{Al}_{2} \mathrm{O}_{3}$ was "pushed" back into the aluminum by the $\mathrm{UAl}_{3}$. This was another confirmation of the greater rate of aluminum diffusion into the uranium than vice-versa, i.e. the Kirkendall effect.

Fig. 8 is a view of the complete effectiveness a thick $\mathrm{H}_{2} \mathrm{SO}_{4}$ electrically produced $\mathrm{Al}_{2} \mathrm{O}_{3}$ film had in preventing U-AI interaction. In this case, the $\mathrm{Al}_{2} \mathrm{O}_{3}$ film was produced by holding the aluminum 30 minutes in the bath. The subsequent reaction couple was then hot-pressed in vacuo against hot-pressed uranium at a temperature of $500^{\circ} \mathrm{C}$ under a pressure of 9 tsi held for 2 minutes.

C. Aluminum-Silicon Eutectic Penetration into Aluminum

As with uranium vs. aluminum, a plot of $\ln D$ vs $\frac{1}{T}$ for Al-Si eutectic penetration into aluminum was a straight line, Fig. 6. This plot for the intermetallic layer penetration into aluminum indicated lower penetration coefficients, for the same temperatures, than for bare uranium vs. aluminum. Calculation also showed a higher activation energy for Al-Si eutectic penetration into aluminum than for uranium into aluminum, see Table I-B.

D. Aluminum-Silicon Eutectic Intermetallic Compound Penetration into Uranium

Unfortunately, as stated previously, the uranium always broke away from the Al-Si eutectic intermetallic layer after reaction and it was not possible to determine the extent of penetration between uranium and this layer.

\section{SUMMARY}

The following is a brief recapitulation of the findings of this report.

A. Uranium-Aluminum Alloying

1. Plots of (In D vs $\frac{1}{T}$ ) for hot-pressed or reguline uranium vs. aluminum experimental penetration data were straight lines. The slopes of these lines gave reasonable activation energies for the process of penetration involved and agreed fairly well with previously published data.

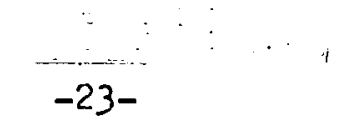




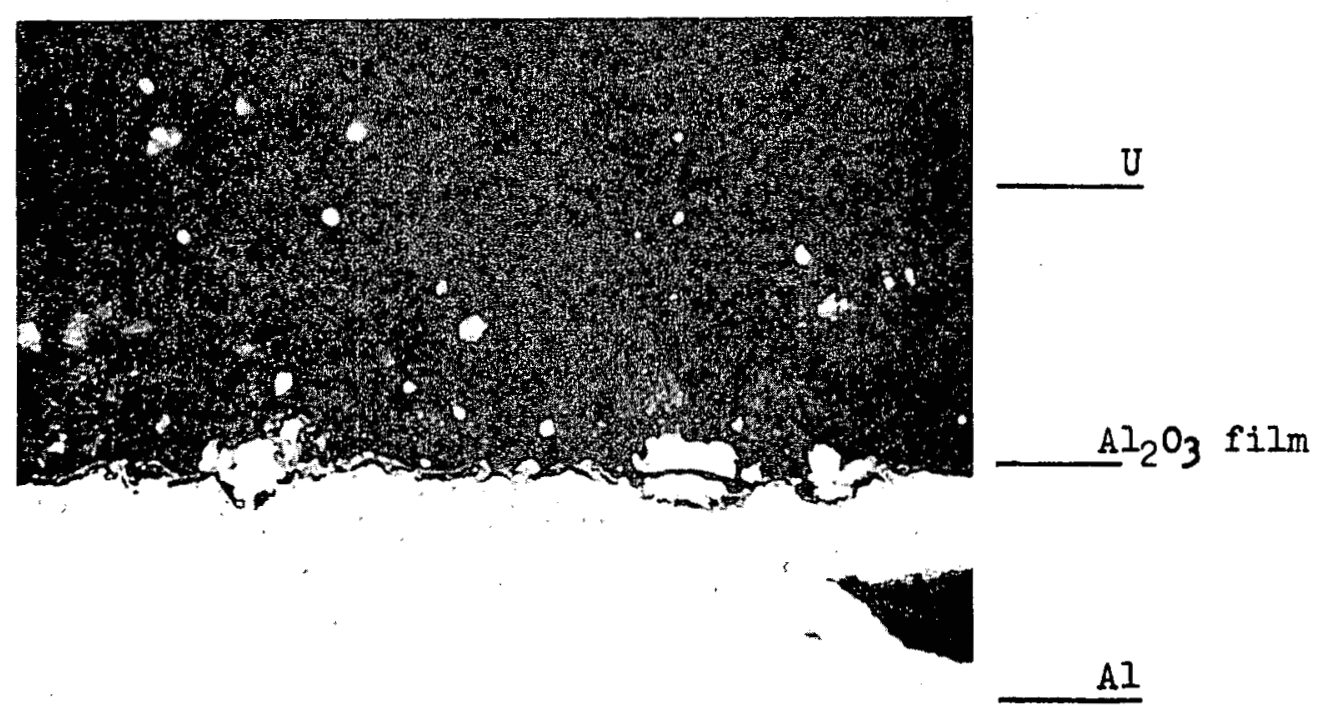

$\checkmark$ Heat Tinted

$500 x$

Fig. 7 - Al treated in Alrok anodizing solution then reacted against $U$ in vacuo at $550^{\circ} \mathrm{C}$ at a pressure of 9 tsi held for 2 minutes. Several intermittent $\mathrm{UAl}_{3}$ penetrations through the thin $\mathrm{Al}_{2} \mathrm{O}_{3}$ film may be noted. Also note how $\mathrm{Al}_{2} \mathrm{O}_{3}$ film is pushed back into the $A l$ at these penetration points.

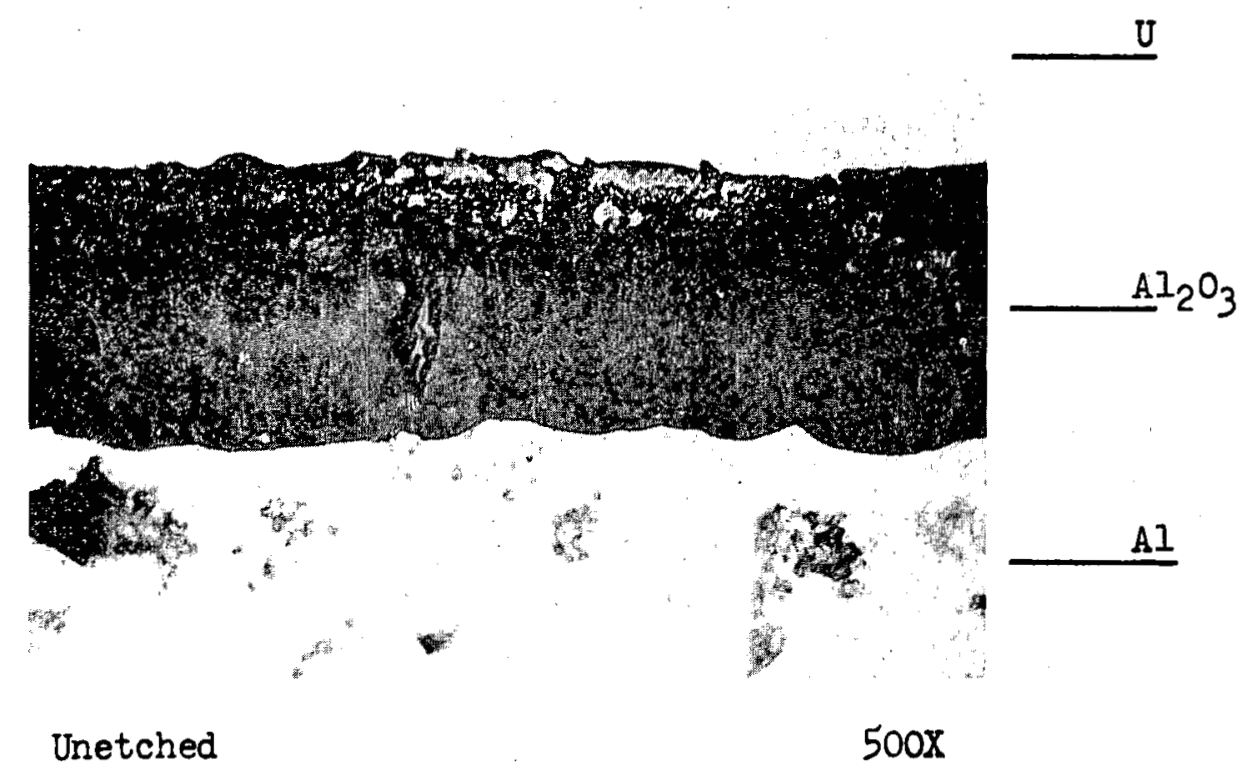

Fig. 8 - Thick anodized layer formed on $\mathrm{Al}$ in $\mathrm{H}_{2} \mathrm{SO}_{4}$ electrolyte and reacted against $U$ at $\mathrm{SOO}^{\circ} \mathrm{C}$ under a pressure of 9 tsi held for 2 minutes. The $\mathrm{Al}_{2} \mathrm{O}_{3}$ film is unbroken and has prevented $U-A I$ interaction. 
V. SUMMARY (cont'd)

2. Increasing the pressure on a U-AI reaction couple during the reaction process caused the rate of penetration to increase.

3. Aluminum diffused into uranium faster than uranium diffused into a luminum.

B. $\mathrm{Al}_{2} \mathrm{O}_{3}$ Barrier Films Between

Uranium and Aluminum

1. Increasing the thicknesses of $\mathrm{Al}_{2} \mathrm{O}_{3}$ films produced by the sulfuric acid, chromic acid or Alumox methods very rapidly decreased the rate of reaction of uranium and aluminum when placed between them. A sufficiently thick $\mathrm{Al}_{2} \mathrm{O}_{3}$ film completely prevented subsequent U-AI reaction.

2. Impervious films were obtained more rapidly with the sulfuric acid anodization method than with any of the others.

3. Phosphoric acid and Alrok type oxide films were not very effective in inhibiting U-AI alloying.

4. Increasing the pressure during the reaction process aided in preventing U-Al alloying.

C. Aluminum-Silicon Butectic Reaction

with Aluminum

1. Plotting in D vs $\frac{1}{T}$ for Al-Si eutectic penetration into aluminum produced a straight line relationship.

2. The activation energy of the Al-Si eutectic-aluminum reaction was greater than that of uranium to aluminum while penetration cofficients were lower for the former than the latter for the same temperature of reaction.

D. Aluminum-Silicon Reaction with

Uranium

It was not possible to determine with the techniques used the effect reactions conditions had upon Al-Si eutectic intermetaliic compound vs. uranium interaction.

$$
3592
$$

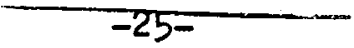


VI. CONCLUSION

The results of this investigation should contribute to a better comprehension of the process of U-AI alloying and to the effect temperature and pressure have upon this phenomenon. The studies of the kinetics of the $\mathrm{OAl}_{3}$ penetration into aluminum are important from the actual point of understanding and possibly preventing reactor slug failure.

Data obtained were reasonable and in fairly good agreement where similar data existed. In addition to obtaining data using reguline uranium, uranium formed by hot-pressing powder compacts was likewise investigated. When reacted against aluminum, slight differences in penetration rates between it and reguline uranium were found to exist.

A much better comprehension was obtained of the quantitative effectiveness $\mathrm{Al}_{2} \mathrm{O}_{3}$ diffusion barrier films had when placed between uranium and alumimum. Here the thickness of the films was varied as well as the methods of obtaining the films. Both were found to have an effect upon subsequent U-AI reaction.

Finally, Al-Si wtectic penetration into aluminum was also investigated and compared to U-Al penetration data. 


\section{APPENDIX}

The technique used for obtaining $\mathrm{Al}_{2} \mathrm{O}_{3}$ film on a $2 \mathrm{~s}$ a luminum specimen was as follows:

1. The aluminum was first made anodic at 6 volts in Oakite Precleaner \#90 for 10 seconds. This was done to degrease and etch the aluminum surfaces.

2. Next the aluminum was pickled in an acid bath for 10 minutes with the bath being held at a temperature of $80^{\circ} \mathrm{C}$. The bath itself was composed of $\mathrm{CrO}_{3}=35$ gms/liter plus $\mathrm{H}_{2} \mathrm{SO}_{4}=176$ gms/liter.

3. The aluminum piece was then anodized in the particular bath desired.

4. After anodization, the aluminum oxide was sealed with steam.

5. Finally, the sealed piece was dried in an oven at $110^{\circ} \mathrm{C}$ for 30 minutes.

The actual anodization treatments were accomplished in the following manner:

\section{ELBCTROLYTIC BATHS}

A. Chromic Acid Anodization

A stainless steel tank used to contain the electrolytic bath was made the cathode. The bath itself was composed of $100 \mathrm{gms} /$ liter of $\mathrm{CrO}_{3}$ held at $35 \pm 5^{\circ} \mathrm{C}$. The starting voltage used was 5 volts which was increased to 40 volts after five minutes had elapsed. The specimen was anodized for the desired length of time after the 40 volts had been attained.

B. Sulfuric Acid Anodization

A glass tank containing a lead cathode was used to hold the electrolyte. The bath was composed of 84 gms/liter of $\mathrm{H}_{2} \mathrm{SO}_{4}$, specific gravity of 1.84 , held at a temperature of $25 \pm 5^{\circ} \mathrm{C}$. The starting voltage was 5 volts which was increased to 18 volts after five minutes. The specimens were held for varying lengths of time after the 18 volts had been applied.

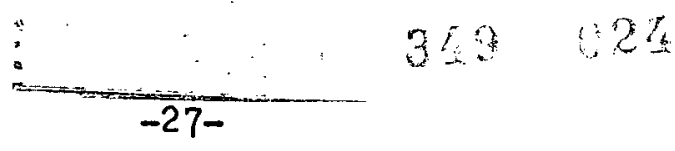




\section{APPEADIX (cont'd)}

\section{BLECTROLYTIC BATHS (cont'd)}

C. Phospnoric Acid Anodization

A glass tank using a lead cathode was used to hold a bath containing $590 \mathrm{gms} /$ liter of $\mathrm{H}_{3} \mathrm{PO}_{4}, 85 \%$. Specimens were anodized in this bath for varying lengths of time at 20 volts.

II. IMMERSION BATHS

A. Alrok Bath

A glass tank was used to contain a bath made of $2.0 \%$ aodium carbonate plus $0.1 \%$ potassium dichromate. The bath was held at $65^{\circ} \mathrm{C}$ and the alumimum was immersed in it for varying lengthe of time.

B. Alumox Bath

A glass tank the containing vessel for the bath utilizing 30 gms/liter of commercially avallable Alumox salt. The bath was held at its boiling temperature while the aluminum specimens ware immersed in it for varying lengths of time. 


\section{BIBLIOGRAPHY}

1. D.W. Bareis, "Studies of the Aluminum-Uranium Alloying Reaction". December 15, 1949, BNI-38.

2. R.0. Williams, "Interin Report on Clinton Slug Ruptures. Causes and Prevention", ORNL-269.

3. H.H. Hausner, J.I. Zambrow, S. Storchheim, "Preliminary Report on New Method of Canning Solid Uranium Slugs in Aluminum", SEP-84.

4. F. Seitz, "Fundamental Aspects of Diffusion in Solids", Phase Transformations in Solids, 1951, John Wiley \& Sons, New York.

5. C.D. Cagle and I.B. Enlet, "Slug Ruptures in the Oak Ridge National Laboratory Pile*, ORNI-170.

6. I.S. Darken, Metals Technol:, Tech. Pub. 2311 (1948)

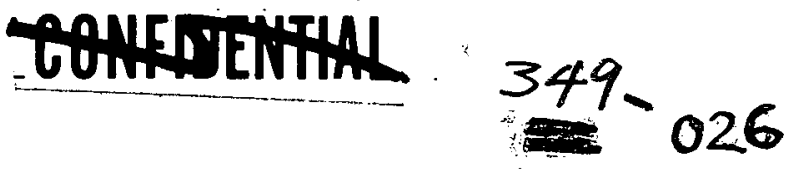

$-29-$ 